\title{
PENGARUH KONSELING GIZI TENTANG KONSUMSI DAUN KATUK DAN KACANG HIJAU DENGAN MEDIA BOOKLET TERHADAP PERILAKU IBU MENYUSUI DI KECAMATAN PERCUT SEI TUAN
}

\author{
Ratna Zahara, Lusyana Gloria Doloksaribu, Rohani Retnauli Simanjuntak \\ ${ }^{1}$ Jurusan Gizi Poltekkes Kemenkes Medan
}

\begin{abstract}
Breastmilk (ASI) is the best life fluid that is needed by babies, containing various important substances for the baby's growth and development according to their needs. The success of breastfeeding is influenced by the nutrients consumed by the mother during pregnancy and breastfeeding. This study was conducted to determine the effect of breastfeeding counseling using bookletters on breastfeeding behavior in Percut Sei Tuan District. This type of research is a quasiexperimental (Quasy experiment) with a pre-test research design and a post-test design with a comparison group. Conducted in March - August 2020, the samples were breastfeeding mothers in Percut Sei Tuan District in Cinta Rakyat Village as an intervention group and breastfeeding mothers in Cinta Damai Village as a comparison group. Samples and controls were selected by "purposive sampling" each of 30 samples. The data consisted of primary data and secondary data, processed and univariate analysis was carried out to see the frequency distribution based on knowledge and attitudes in the menu selection of breastfeeding mothers followed by bivariate analysis using the dependent $t$-test to compare knowledge, attitudes and actions of respondent eating before (pre) and after (post) counseling. From the research conducted, there were differences in the knowledge of mothers from the intervention group and the comparison group, there were differences in attitudes in the two groups, and there were differences in actions in the two groups after counseling using booklet media.
\end{abstract}

Booklet-based counseling influences the mother's actions in breastfeeding her baby.

Keywords: breastfeeding, counseling, booklets, breastfeeding behavior

\section{PENDAHULUAN}

The World Alliance for Breastfeeding Action (WABA) pada tahun 2007 memperkirakan 1 juta bayi dapat diselamatkan setiap tahunnya bila diberikan ASI pada satu jam pertama kelahiran. Dengan pemberian ASI dalam 1 jam pertama, bayi akan mendapatkan zat gizi yang penting dan mereka terlindungi dari berbagai penyakit berbahaya pada masa yang paling rentan dalam kehidupannya (Paramita,2011). Hasil Riskesdas 2013 menunjukkan pemberian ASI kurang dari satu jam meningkat menjadi $34,5 \%$ dari $29,3 \%$ pada tahun 2010 . Angka tertinggi di Nusa Tenggara Barat, yaitu 52,9\% dan terendah di Papua Barat, yaitu 21,7\%. Namun, angka ini masih dibawah target pencapaian oleh UNICEF yaitu $80 \%$. Oleh karena itu diperlukan usaha-usaha untuk memperbaiki pemberian ASI.

Menurut hasil survei Demografi dan Kesehatan Indonesia 2002 - 2012, kematian balita, bayi, dan neonatus di Indonesia cenderung menurun. Pada tahun 2012, Angka Kematian Balita sebesar 32/1000 kelahiran hidup, bayi 23/1000 kelahiran hidup, dan neonates 14/1000 kelahiran hidup. Dari jumlah total 146.739 kematian,52\% terjadi di 5 propinsi, yaitu Jawa Barat $16 \%$, Jawa Tengah $12 \%$, Jawa Timur $11 \%$, Sumatera Utara $8 \%$, dan Banten 5\%. Sedangkan $48 \%$ lainnya terjadi di 28 propinsi seperti Aceh 3\%, NTB 4\%, NTT3\%, Sumatera Selatan 3\% (Direktorat Jendral GIKIA2002-2012).
Air susu ibu (ASI) adalah cairan kehidupan terbaik yang sangat dibutuhkan oleh bayi. ASI mengandung berbagai zat yang penting untuk tumbuh kembang bayi dan sesuai dengan kebutuhannya. Dis isi la in, ada ibu yang ingin menyusui bayinya tetapi mengalami kendala. Biasanya ASI tidak mau keluar atau produksinya kurang lancar. Produksi dan pengeluaran ASI dipengaruhi oleh dua hormon, yaitu prolaktin dan oksitosin. Prolaktin mempengaruhi produksi ASI, sementara oksitosin bekerja untuk proses pengeluaran ASI. Prolaktin berkaitan dengan gizi ibu, makin baik asupan gizi ibu, makin banyak ASI yang dihasilkan (Juliastuti, 2019).

Di Indonesia, daun katuk sudah dimanfaatkan sebagai sediaan fitofarmaka yang berkhasiat untuk melancarkan ASI. Selain itu, konsumsi sayur katuk oleh ibu menyusui dapat memperlama waktu menyusui bayi. Daun katuk merupakan tanaman lokal yang memiliki kadar klorofil tinggi, mengandung antioksidan dalam jumlah besar yang sangat bermanfaat untuk mencegah radikal bebas dan mencegah penuaan dini, anemia, meningkatkan absorsi gizi di saluran cerna, mengatasi kelelahan, dan menghambat terjadinya gangguan pembuluh darah (Endang S, 2016).

Berdasarkan Angka Kecukupan Gizi (AKG) bagi bangsa Indonesia, ibu yang sedang menyusui bayi umur hingga 6 bulan memerlukan tambahan kecukupan energi sebesar 330 kkal dan tambahan kecukupan protein sebesar 20 g (Kemenkes RI, 2016). Hasil survei 
konsumsi pangan individu di Indonesia tahun 2014 memperlihatkan banyak dari kelompok umur ibu menyusui dengan konsumsi energi dan protein pada kategori kurang yaitu sebanyak $50 \%$ dengan konsumsi energi< $>70 \%$ dari $\mathrm{AKG}$ dan sebanyak 33,8\% dengan konsumsi protein $<80 \%$ AKG (Kemenkes RI, 2016).

Salah satu jenis kacang-kacangan yang mengandung zat besi tinggi adalah kacang hijau (vigna radiata). Kacang hijau sangat bermanfaat bagi kesehatan ibu hamil dan menyusui, juga untuk menunjang masa pertumbuhan anak (Akbar, 2015). Kandungan zat besi dalam kacang hijau paling banyak terdapat pada embrio dan kulit bijinya (Astawan, 2009) dengan jumlah kandungan zat besi pada kacang hijau sebanyak 6,7 mg per 100 gram kacang hijau(Dewi, 2017).

Persagi (2010) mendefinisikan konseling gizi adalah suatu bentuk pendekatan yang digunakan dalam asuhan gizi untuk menolong individu dan keluarga memperoleh pengertian yang lebih baik tentang dirinya dan permasalahan yang dihadapi. Peran penting yang menentukan keberhasilan adalah pemahaman, pengetahuan, dan kepatuhan pasien.

Booklet merupakan salah satu media yang dapat digunakan untuk menyampaikan informasi lebih mendalam. Penggunaan media booklet sendiri memiliki kelebihan yaitu informasi didalamnya dapat dilihat kapan saja dan dimana saja serta dapat dipelajari secara mandiri sehingga lebih efektif dalam penyampaian pesan yang diharapkan mampu meningkatkan pengetahuan, sikap dan diharapkan berlanjut dengan perubahan perilaku.

Dari uraian diatas peneliti tertarik untuk melakukan penelitian dengan judul Pengaruh Konseling GiziTentang Konsumsi Daun Katuk dan Kacang Hijau Dengan Media Booklet Terhadap Perilaku Ibu Menyusui di Kecamatan Percut Sei Tuan.

\section{TUJUAN PENELITIAN}

1. Untuk mengetahui pengetahuan, sikap dan dukungan Suami Ibu menyusui di Desa Cinta Rakyat dan Desa Tanjung Rejo, Kecamatan PercutSei Tuan, Kabupaten Deli Serdang.

2. Menilai pengetahuan sebelum dan setelah konseling pada Ibu menyusui di Kecamatan Percut Sei Tuan

3. Menilai sikap sebelum dan setelah konseling pada pada Ibu menyusui di Desa Kecamatan Sei Tuan

4. Menilai perilaku menyusui sebelum dan setelah di berikan konseling pada ibu menyusui di Kecamatan Percut Sei Tuan.

5. Menganalisis pengaruh Pengaruh Konseling Gizi Tentang Konsumsi Daun Katuk dan Kacang Hijau Dengan Media Booklet Terhadap Perilaku Ibu Menyusui di Kecamatan Percut Sei Tuan.

\section{METODE PENELITIAN}

\section{Desain, Subjek, dan Waktu}

Penelitian ini merupakan jenis penelitian Quasi Eksperimen Design dengan rancangan penelitian pre-test dan post-test design dengan kelompok pembanding. Rancangan penelitian sebelum dan sesudah intervensi dengan menggunakan kelompok pembanding disajikan secara skematik. Pre-test dilakukan sebelum perlakuan. Post-test dilakukan 14 hari setelah perlakuan. Sampel dalam penelitian ini adalah ibu menyusuiyang berdomisili di desa Cinta Rakyat dan Desa Cinta Damai. Sampel terdiri dari sampel kasus dan sampel kontrol. Kelompok ekperimen adalah ibu menyusui yang memiliki bayi berusia 0-6 bulan dan Kelompok kontrol adalah ibu menyusui yang memiliki bayi berusia 0-6 bulan.

\section{Jenis dan Cara Pengumpulan Data}

Data yang dikumpulkan dalam penelitian ini terdiri dari data primer dan data sekunder. Data primer didapatkan langsung dari wawancara dan pengisian kuesioner dengan sampel, sementara data sekunder didapatkan dari data desa.

\section{Pengolahan dan Analisis Data}

Analisa data diperoleh dengan menggunakan perhitungan uji statistik memakai program SPSS. Analisa Univariat digunakan untuk mendeskripsikan setiap variabel penelitian. Analisis bivariat digunakan untuk untuk membandingkan Pengetahuan, Sikap dan Perilaku menyusui responden dan melihat adanya signifikan dalam menbandingkan Sebelum (pre) dan sesudah (post) diberikan Konseling.

\section{HASIL DAN PEMBAHASAN}

\section{Karakteristik Subjek}

Adapun karakteristik ibu menyusui bayi usia 0-6 bulan. Subjek meliputi umur, pendidikan.

Umur merupakan salah satu faktor yang mempengaruhi produktifitas individu. Usia ibu sangat menentukan timbulnya sikap keibuan dari ibu yang berkaitan dengan kondisi kehamilan, persalinan dan nifas sampai mengasuh dan menyusui bayinya. Ibu yang berumur dibawah 20 tahun masih belum matang dan belum cukup siap secara jasmani dan sosial dalam menjalani porses kehamilan, persalinan serta dalam. membina bayi. Berdasarkan usia, responden paling banyak berada di kelompok usia 20 - 25 Tahun, sebanyak $38,3 \%$, dimana di kelompok intervensi sebanyak 33,3\% dan kelompok pembanding sebanyak 43,3\%.

Tingkat pendidikan ibu yang rendah dapat mengakibatkan kurangnya pengetahuan ibu dalam menghadapi sebuah masalah, terutama pada saat proses pemberian ASI Eksklusif. Pendidikan mempunyai kaitan dengan pengetahuan ibu menyusui dalam memberikan ASI eksklusif. Hal ini dapat dilihat bahwa seseorang yang berpendidikan lebih tinggi akan mempunyai pengetahuan yang lebih luas dibandingkan dengan seseorang yang berpendidikan lebih rendah. 
Hasilpenelitian menunjukkan bahwa mayoritas tingkat pendidikan responden berada responden paling banyak berpendidikan tingkat SLTA, sebesar 48,3\%, dimana di kelompok intervensi, responden dengan pendidikan SLTA sebanyak $46,7 \%$ dan kelompok pembanding sebanyak $50 \%$.

Lingkungan seseorang bekerja dapat menjadikan seseorang mendapatkan pengalaman dan pengetahuan baik secara langsung atau pun secara tidak langsung.

Pengetahuan merupakan hasil penginderaan manusia, atau hasil dari tahu seseorang terhadap objek melalui indera yang dimilikinya yang di pengaruhi oleh intensitas perhatian dan persepsi terhadap suatu objek (Notoatmodjo, 2010).

\section{Tabel 1. Pengetahuan Responden Pre- Konseling dan} Post Konseling

\begin{tabular}{|c|c|c|c|c|c|c|c|c|c|c|c|}
\hline \multirow{3}{*}{$\begin{array}{l}\text { Pengeta } \\
\text { luan }\end{array}$} & \multicolumn{3}{|c|}{ Kebmpol Intercensi } & \multicolumn{4}{|c|}{ Kelompol Pembanding } & \multicolumn{4}{|c|}{ Total } \\
\hline & & Inling & $\begin{array}{l}\text { Post } \\
\text { konselin }\end{array}$ & & $\begin{array}{l}\text { Pre } \\
\text { neeling }\end{array}$ & & osst & & & & $\begin{array}{l}\text { Poit } \\
\text { mephing }\end{array}$ \\
\hline & $\mathbb{1 1}$ & of & $\mathbb{1}$ & II & of & $n$ & 90 & $\mathbb{1}$ & yo & $\mathbb{1}$ & $y_{0}$ \\
\hline & 1 & 3,3 & 2790 & 2 & 6,7 & 5 & 16,7 & 3 & j & & 53.3 \\
\hline & 29 & 967 & 310 & 20 & 93,3 & 25 & 0,3 & 57 & 95 & 28 & \\
\hline & 3 & 100 & 3010 & 3 & 100 & 30 & & 0 & 100 & 60 & 100 \\
\hline
\end{tabular}

Hasil penelitian menunjukkan bahwa kategori Pengetahuan Pre dan Post Test responden, dimana untuk Pre test kelompok intervensi memiliki kategori pengetahuan Kurang sebanyak 96,7\% dan kategori baik sebanyak 3,3\%. Dan untuk post test, kategori baik sebesar 90\% dan kategori kurang 10\%, sedangkan untuk Kelompok Pembanding, untuk pre test memiliki kategori pengetahuan Kurang sebanyak 93,3\% dan kategori baik sebanyak $6,7 \%$. Dan untuk post test, kategori baik sebesar $16,7 \%$ dan kategori kurang $83,3 \%$.

Tabel 2. Sikap Responden Pre- Konseling dan Post Konseling

\begin{tabular}{|c|c|c|c|c|c|c|c|c|c|c|c|c|}
\hline \multirow{3}{*}{ Sillap } & \multicolumn{4}{|c|}{ Kelompok Inferrenci } & \multicolumn{4}{|c|}{ Kebnpok Fe mbanding } & \multicolumn{4}{|c|}{ Total } \\
\hline & & Pre & & ost & & $\begin{array}{l}\text { Pre } \\
\text { wellip: }\end{array}$ & & ost & $\begin{array}{r}\text { Pr } \\
\text { Kous }\end{array}$ & & & silise \\
\hline & $n$ & 16 & a & 6 & 1 & $Q_{j}$ & $n$ & of & n & 10 & 1 & Qh \\
\hline ik & 2 & $2, i$ & 28 & 96,7 & 4 & 133 & 7 & 23,2 & 6 & 10 & 30 & 233 \\
\hline mang & 28 & 033 & 1 & 3.3 & 26 & 86.7 & 23 & 76,7 & 54 & 90 & 24 & 76.7 \\
\hline Toull & 30 & 100 & 30 & 100 & 3) & 110 & 30 & 100 & 60 & 1000 & 80 & 100 \\
\hline
\end{tabular}

Hasil penelitian untuk kategori Sikap Pre dan Post Test responden, dimana untuk Pre test kelompok intervensi memiliki kategori sikap Kurang sebanyak 93,3\% dan kategori baik sebanyak 2,7\%. Dan untuk post test, kategori baik sebesar 96,7\% dan kategori kurang 3,3\%, sedangkan untuk Kelompok Pembanding, untuk pre test memiliki kategori pengetahuan Kurang sebanyak $86,7 \%$ dan kategori baik sebanyak 13,3\%. Dan untuk post test, kategori baik sebesar 23,2\% dan kategori kurang $76,7 \%$.

Tabel 3. Tindakan Responden Pre- Konseling dan Post Konseling

\begin{tabular}{|c|c|c|c|c|c|c|c|c|c|c|c|c|}
\hline \multirow{3}{*}{ Tindakan } & \multicolumn{4}{|c|}{ Kelompok Intervensi } & \multicolumn{4}{|c|}{ KelompokPembanding } & \multicolumn{4}{|c|}{ Total } \\
\hline & & $\begin{array}{l}\mathrm{Pt} \\
\text { ylimg }\end{array}$ & & $\begin{array}{l}\text { ost } \\
\text { seling }\end{array}$ & & & & & $\begin{array}{r}P \\
\text { Kons }\end{array}$ & & & Post \\
\hline & 11 & 90 & 11 & 90 & II & of & 11 & 90 & $\|$ & 90 & $n$ & of \\
\hline Bail: & 2 & 2,7 & 30 & 100 & 0 & 0 & 2 & 2,7 & 2 & 3,2 & 32 & 53,3 \\
\hline Kvern! & 28 & 93,3 & 0 & 0 & 30 & 100 & 28 & 97,3 & 58 & 96,7 & 28 & 46,7 \\
\hline Total & 30 & 100 & 30 & 100 & 30 & 100 & 30 & 100 & 60 & 100 & 60 & 00 \\
\hline
\end{tabular}

Hasil penelitian untuk kategori Tindakan pre dan Post Test responden, dimana untuk Pre test kelompok intervensi memiliki kategori tindakan Kurang sebanyak 93,3\% dan kategori baik sebanyak 2,7\%. Dan untuk post test, semua responden memiliki sikap yang baik, sebesar $100 \%$, sedangkan untuk Kelompok Pembanding, untuk pre test memiliki kategori sikap Kurang sebanyak $100 \%$ , setelah dilakukan konseling, kategori baik sebesar 2,7\% dan kategori kurang $97,3 \%$. 


\section{Tabel 4. Perbandingan Rerata Nilai Skor Pretest Dan Posttest Tindakan Menyusui pada Kelompok Intervensi Dan Pembanding}

\begin{tabular}{|c|c|c|c|c|c|c|c|}
\hline \multirow{3}{*}{$\begin{array}{l}\text { Kelomp } \\
\text { ok } \\
\text { Penyulu } \\
\text { han Gizi }\end{array}$} & \multicolumn{6}{|c|}{ Tindakan Menyusui } & \multirow{3}{*}{$\begin{array}{l}\text { Selisih } \\
\text { Rerata } \\
\text { Skor }\end{array}$} \\
\hline & \multicolumn{3}{|c|}{$\begin{array}{c}\text { Sebelum } \\
\text { Penyuluhan }\end{array}$} & \multicolumn{3}{|c|}{$\begin{array}{c}\text { Setelah } \\
\text { Penyuluhan }\end{array}$} & \\
\hline & $\begin{array}{c}\text { Me } \\
\text { an }\end{array}$ & $t$ & $p$ & $\begin{array}{c}\text { Mea } \\
\text { n }\end{array}$ & $t$ & $p$ & \\
\hline $\begin{array}{l}\text { Kelompo } \\
\mathrm{k}\end{array}$ & 7,14 & & & 7,47 & & & 0,33 \\
\hline $\begin{array}{l}\text { Intervensi } \\
\text { Kelomp } \\
\text { ok } \\
\text { Pemban } \\
\text { ding }\end{array}$ & 7,03 & $\begin{array}{c}- \\
2,34 \\
0\end{array}$ & $\begin{array}{c}0,02 \\
6\end{array}$ & 7,03 & $\begin{array}{c}0,23 \\
1\end{array}$ & 0,00 & 0,00 \\
\hline
\end{tabular}

Dari tabel diatas dapat dilihat nilai rerata skor tindakan kelompok penyuluhan gizi dengan media booklet lebih besar dari pada penyuluhan tanpa menggunakan media (metode ceramah) yaitu dari 7,14 menjadi sebesar 7,47 dengan selisih rerata skor sebesar 3,40 . Hal ini menunjukkan bahwa penyuluhan gizi dengan media booklet lebih efektif merubah tindakan responden dalam menyusui daripada penyuluhan dengan metode ceramah tanpa menggunakan media.

Hasil penelitian ini membuktikan bahwa penggunaan media booklet sebagai edukasi gizi untuk pemilihan makanan lebih efektif dibandingkan dengan metode edukasi dengan ceramah. Penyuluhan dengan media booklet dapat memberikan materi yang lebih lengkap dan ukurannya yang kecil sehingga lebih memudahkan untuk membaca booklet di mana saja (Azadirachta dan Sumarmi, 2017).

Peningkatan tindakan responden dalam memilih makanan ibu menyusui dapat dilihat dari banyaknya responden yang mengetahui berbagai informasi tentang sumber nutrisi .

Penyuluhan gizi dengan menggunakan media booklet tentang Gizi ibu menyusui dapat meningkatkan perilaku keamanan pangan. Hal ini sesuai dengan pendekatan Green (1980) yang menjelaskan pendekatan edukasional dan pemaparan media dapat merubah perilaku seseorang, dimana intervensi yang diberikan merupakan proses pendidikan kesehatan untuk merubah perilaku. Booklet diberikan kepada responden untuk dibawa pulang sehingga responden dapat melihat dan membaca informasi yang ada di booklet tersebut yang bertujuan memberikan informasi, nasihat, memberikan arah dan petunjuk. Selain itu, menurut Skiner dalam Notoadmodjo (2010) menjelaskan bahwa stimulus yang diberikan kepada organisme dapat menghasilkan respon yang lebih baik. Penyuluhan gizi dengan media booklet merupakan stimulus yang diberikan agar ibu menyusui merespon dan bertindak sesuai dengan pesan-pesan yang disampaikan. Sebuah pesan dapat diterima dengan baik oleh komunikan apabila terdapat perhatian yang besar di benak komunikan, dalam hal ini pesan gizi untuk ibu menyusui dapat diterima baik oleh responden sehingga terjadi peningkatan perilaku menyusui

\section{KESIMPULAN}

1. Ada peningkatan pengetahuan sebelum dan setelah konseling pada Ibu menyusui di Kecamatan Percut Sei Tuan

2. Ada perubahan sikap yang lebih baik pada ibu menyusui di kecamatan Percut Sei Tuan setelah dilakukan konseling dengan menggunakan media Booklet

3. Ada perubahan perilaku menyusui pada ibu menyusui di kecamatan percut sei tuan setelah dilakukan konseling dengan media booklet

4. Pengaruh Konseling GiziTentang Konsumsi Daun Katuk dan Kacang Hijau Dengan Media Booklet memberikan pengaruh terhadap Perilaku Ibu Menyusui di Kecamatan Percut Sei Tuan.

\section{SARAN}

Perlu adanya program lanjutan berupa pelatihan pengolahan makanan berbasis daunkatuk dan kacang hijau sebagai alternatif makanan sehat bagi ibu hamil dan menyusui di Kecamatan percut Sei Tuan, agar kelak konsumsi makanan yang ada di lingkungan sekitar menjadi perilaku yang baik.

\section{DAFTAR PUSTAKA}

Agustin, Maria et al. (2014). Efektifitas Pendidikan Kesehatan Media Booklet Dibandingkan Dengan Audiovisual Terhadap Pengetahuan Orang Tua Tentang Karies Gigi Pada Anak Usia 5 - 9 Tahun Di Desa Makam Haji.

Almatsier, Sunita. (2009). Prinsip Dasar Ilmu Gizi. Jakarta: GramediaAzis S dan Muktiningsih SR. (2006). Studi Manfaat Daun Katuk (Sauropus androgynus), Cermin Dunia Kedokteran; 151:4850 .

Anonim. 2014. Breastfeeding Report Card United States 2013, National Center for Chronic Diseases Control and Prevention and Health promotion. Diakses 312-201415:15

Apriani, Arista dan Mei Lina Fitri Kumalasari. 2014. Pengaruh Pendidikan Kesehatan Dengan Booklet Terhadap Pengetahuan Dan Sikap Tentang Deteksi Dini Kanker Payudara Pada WUS Di Surakarta Jawa Tengah. 
Arifin, Siregar. 2006. Pemberian ASI Eksklusif dan Faktor-Faktor yang Mempengaruhinya. Sumatera Utara: Universitas Sumatera Utara.

Arikunto, S. 2010. Manajemen Penelitian. Reka Cipta.

Artini, Friza Rahmi et al. 2014. Perbedaan Pengaruh Pendidikan Kesehatan Menggunakan Media Leaflat Dengan Booklet Terhadap Tingkat Pengetahuan Masyarakat Tentang Chikungunya Di Desa Trangsan Gatak Sukoharjo. Skripsi Fakultas Ilmu Kesehatan Universitas Muhammadiyah Surakarta

Asdi, Ratna. (2018). Hubungan Pengetahuan dan Status Pekerjaan Ibu dengan Pemberian ASI Eksklusif di Desa Sambi, Kecamatan Sambi, Boyolali. Skripsi. Fakultas Ilmu Kesehatan, Universitas Muhammadiyah Surakarta.

Hikmawati, Isna.2008. Faktor - Faktor Risiko Kegagalan Pemberian ASI Selama Dua Bulan. Tesis Program Pascasarjana Universitas Diponegoro Semarang. Diakses melalui http\%3A\%2F\%2Feprints.undip.ac.id. Pada Tanggal 5 Mei 2013. Pukul 19.12WIB

Ida. (2012). Faktor-Faktor Yang Berhubungan Dengan Pemberian Asi Eksklusif 6 Bulan Di Wilayah Kerja Puskesmas Kemiri Muka Kota Depok Tahun 2011. Tesis.

Iramaya Sari, \& Lestari, A. (2019). Faktor-faktor Yang Mempengaruhu Pemberian ASI Eksklusif Pada Ibu Nifas di Wilayah Kerja Puskesmas Bonto Bahari Kabupaten Bulukumba.. Jurnal Kesehatan Panrita Husada. ttps://doi.org/10.37362/jkph.v3i1.9

Kemenkes RI,1995. Modul Manajemen Laktasi. Direktorat Jenderal Pelatanan Medik. Jakarta

Malikatul Ma'munah. (2013).Pengaruh Pendidikan Kesehatan Dengan Booklet Terhadap Pengetahuan Ibu Laktasi Di Wilayah Kerja Puskesmas Ciputat Timur. Universitas Islam Negeri Syarif hidayatullah Jakarta 